\title{
Catecholamine resistance in fat cells of women with upper-body obesity due to decreased expression of beta ${ }_{2}$-adrenoceptors
}

\author{
S. Reynisdottir ${ }^{1}$, H. Wahrenberg ${ }^{1}$, K. Carlström ${ }^{1}$, S. Rössner ${ }^{2}$, P. Arner ${ }^{1}$ \\ ${ }^{1}$ Research Center, Department of Medicine, Huddinge Hospital, Karolinska Institute, Sweden \\ ${ }^{2}$ Department of Medicine, Karolinska Hospital, Karolinska Institute, Stockholm, Sweden
}

\begin{abstract}
Summary Upper-body obesity is an important risk factor for developing non-insulin dependent diabetes. To investigate the possibility that a lipolysis defect is present in this form of obesity, we examined the adrenergic regulation of lipolysis in abdominal subcutaneous fat cells from 25 women with upper-body obesity and 24 non-obese women. Lipolytic noradrenaline sensitivity (but not the maximum rate of lipolysis) was reduced by 10 -fold in obese women $(p<0.01)$. The noradrenaline resistance could be ascribed to a 10 -fold decrease in lipolytic beta ${ }_{2}$-adrenoceptor sensitivity $(p<0.01)$. The lipolytic sensitivity of beta $_{1-}$ and alpha $_{2}$-adrenergic receptors was normal in the obese women. A $70 \%$ reduction in the cell surface density of beta $_{2}$-adrenoceptors was observed compared to the control subjects $(p<0.01)$. However, beta ${ }_{1}$-receptor density as well as steady-state mRNA levels for beta ${ }_{1}$ and beta-receptors were normal in obese women.
\end{abstract}

Lipolytic noradrenaline sensitivity correlated inversely with BMI (adjusted $r^{2}=0.76$ together with fat cell volume in stepwise regression analysis). The fasting plasma level of free cortisol was $30 \%$ lower in obese compared to non-obese women $(p<0.05)$ but obesity did not influence resting plasma catecholamine levels. Thus, lipolytic catecholamine resistance is present in abdominal obesity, due to low density of beta $a_{2}$-adrenoceptors, which in its turn may be caused by a post-transcriptional defect in beta -recep- $^{-}$ tor expression. Whether abnormalities in circulating free cortisol levels have caused the impaired lipolytic function of these receptors in upper-body obesity remains to be established. [Diabetologia (1994) 37: 428435]

Key words Adipose tissue, beta-adrenoceptors, alphaadrenoceptors, lipolysis, mRNA
Upper-body obesity is an important risk factor for developing non-insulin dependent diabetes mellitus. Although over-eating and physical inactivity are involved in the pathogenesis of obesity, endogenous factors, which are not well-defined, are also likely to contribute. Disturbances in the regulation of the energy balance may play a role in the development of obesity in certain individuals [1]. An attractive hypothesis is that a defect may exist in the control of mobilization of li-

Received: 30 August 1993

and in revised form: 15 November 1993

Corresponding author: Dr. P. Arner, Department of Medicine, Huddinge Hospital, S-141 86 Huddinge, Sweden

Abbreviations: ED50: Hormone concentration giving half maximum effect; $\mathrm{pD}_{2}$ : negative logarithm of ED50; amol: $10^{-18} \mathrm{~mol}$. pids through lipolysis from fat depots of obese subjects. Lipolysis is under intense hormonal control. In humans, catecholamines play a major role as they are the only hormones with a pronounced and acute lipolytic effect in adipose tissue of adult subjects [2].

Lipolysis in human fat cells can be stimulated by catecholamines through beta $a_{1}$-and beta -adrenocep- $^{-}$ tors, and inhibited through alpha ${ }_{2}$-adrenoceptors. The receptor subtypes should be considered separately. They can be regulated independently and the lipolytic effect of catecholamines depends upon the balance between stimulatory beta-receptors and inhibitory alpha $_{2}$-receptors $[2,3]$. Little is known about adrenergic receptors in human obesity [4]. Previous investigations in vivo have shown blunted lipolytic effects of intravenous doses of catecholamines in obese subjects [5-7], which is most apparent in subjects with abdominal obesity [6]. However, a more detailed in vitro exam- 
ination of hormone-receptor interaction is necessary in order to evaluate the adrenoceptor status of fat cells in obesity. Several studies of experimental obesity, using different animal models, have shown altered function and expression of adipocyte alpha $\mathrm{a}_{2}$ and beta-adrenoceptors [8-12]. In this study, the lipolytic function, expression and pharmacological properties of several adrenoceptor subtypes have been investigated in abdominal subcutaneous adipocytes of non-obese women and women with upper-body obesity.

\section{Subjects and methods}

\section{Patients and experimental protocol}

The study comprised 25 women with upper-body obesity who were otherwise healthy and 24 healthy control women who never had been obese. Upper-body (abdominal) obesity was defined as BMI greater than $27.5 \mathrm{~kg} / \mathrm{m}^{2}$ and waist-hip ratio greater than 0.87 . The latter value is mean $-1 \mathrm{SD}$ of the waisthip ratio of a group of well-characterized Swedish women with abdominal obesity [13]. The subjects were not taking any medication. None had undertaken a weight reducing diet during the year preceding the study. They were either sedentary or undertook moderate exercise less than twice a week. Two women in each group were post-menopausal. The study was explained in detail to each participant and consent was obtained. It was approved by the ethics committee at the Karolinska Institute.

The women were examined at 08.00 hours after an overnight fast. For the pre-menopausal women this was done in the follicular phase of the menstruation cycle. First, after 30-min rest in the supine position, a venous plasma sample was obtained for the analysis of catecholamines [14], insulin, cortisol and the corticosteroid-binding globulin transcortin (commercial RIA assay from Kabi-Pharmacia, Uppsala, Sweden; Diagnostic Products, Calif., USA, and Medgenix Diagnostics SA, Fleurns, Belgium, respectively), as well as for glucose, cholesterol, HDL-cholesterol and triglycerides (the hospital's routine chemistry laboratory). Free plasma cortisol was calculated using total cortisol and transcortin as described by the manufacturer's instructions. Then a subcutaneous fat biopsy (2-3 g) was obtained during local anaesthesia from the abdominal area immediately to the left or right of the umbilicus.

\section{Isolation of fat cells and determination of fat cell size and number}

Isolated fat cells were prepared according to the collagenase method described by Rodbell [15]. Direct microscopic determination of the diameter of 100 fat cells was performed as described [16]. The coefficient of variation in ten experiments was $3 \%$. The same value was obtained using 200 cells. Mean fat cell volume, surface area and weight were determined as described [17].

The number of fat cells incubated were determined as follows. The lipid content was determined gravimetrically after extraction according to Dole and Meinertz [18]. The lipid content of the incubated fat cells was then divided with the mean fat cell weight, assuming that lipids constitute more than $95 \%$ of the fat cell weight. This common method to determine fat cell number [19-21] was compared with a direct method [22], where all cells are counted in appropriately diluted aliquots of the cell suspension [22]. The correlation coefficient between the two methods as determined by linear regression analysis $(n=10)$ was 0.97 .
Table 1. Clinical data for healthy non-obese control subjects and obese subjects

\begin{tabular}{|c|c|c|c|}
\hline & $\begin{array}{l}\text { Control } \\
\text { subjects }\end{array}$ & $\begin{array}{l}\text { Obese } \\
\text { subjects }\end{array}$ & $p$ \\
\hline Age (years) & $36 \pm 3$ & $41 \pm 2$ & NS \\
\hline BMI $\left(\mathrm{kg} / \mathrm{m}^{2}\right)$ & $22.5 \pm 0.5$ & $36.2 \pm 0.8$ & - \\
\hline Waist-hip ratio & $0.86 \pm 0.01$ & $0.96 \pm 0.01$ & - \\
\hline Glucose $(\mathrm{mmol} / \mathrm{l})$ & $4.7 \pm 0.1$ & $5.4 \pm 0.2$ & $<0.001$ \\
\hline Insulin (mU/ml) & $7 \pm 1$ & $14 \pm 1$ & $<0.001$ \\
\hline $\begin{array}{l}\text { Total cortisol } \\
(\mathrm{nmol} / 1)\end{array}$ & $493 \pm 31$ & $347 \pm 31$ & $<0.01$ \\
\hline $\begin{array}{l}\text { Free cortisol } \\
(\mathrm{nmol} / 1)\end{array}$ & $29 \pm 4$ & $18 \pm 1$ & $<0.05$ \\
\hline $\begin{array}{l}\text { Noradrenaline } \\
(\mathrm{nmol} / \mathrm{l})\end{array}$ & $1.9 \pm 0.8$ & $1.8 \pm 0.1$ & NS \\
\hline $\begin{array}{l}\text { Adrenaline } \\
(\mathrm{nmol} / \mathrm{l})\end{array}$ & $0.13 \pm 0.02$ & $0.11 \pm 0.01$ & NS \\
\hline $\begin{array}{l}\text { Glycerol } \\
(\mu \mathrm{mol} / \mathrm{l})\end{array}$ & $70 \pm 8$ & $134 \pm 12$ & $<0.05$ \\
\hline $\begin{array}{l}\text { Pulse } \\
\text { (beats/min) }\end{array}$ & $68 \pm 2$ & $72 \pm 2$ & NS \\
\hline $\begin{array}{l}\text { Systolic blood pressure } \\
(\mathrm{mm} \mathrm{Hg})\end{array}$ & $118 \pm 3$ & $128 \pm 3$ & $<0.05$ \\
\hline $\begin{array}{l}\text { Diastolic blood pres- } \\
\text { sure }(\mathrm{mm} \mathrm{Hg})\end{array}$ & $71 \pm 2$ & $78 \pm 2$ & $<0.05$ \\
\hline $\begin{array}{l}\text { Fat cell volume } \\
\text { (pl) }\end{array}$ & $483 \pm 31$ & $903 \pm 32$ & $<0.001$ \\
\hline $\begin{array}{l}\text { Cholesterol } \\
(\mathrm{mmol} / \mathrm{l})\end{array}$ & $5.1 \pm 0.2$ & $6.0 \pm 0.3$ & $<0.05$ \\
\hline $\begin{array}{l}\text { HDL-cholesterol } \\
(\mathrm{mmol} / \mathrm{l})\end{array}$ & $1.7 \pm 0.1$ & $1.4 \pm 0.1$ & $<0.05$ \\
\hline $\begin{array}{l}\text { Triglycerides } \\
(\mathrm{mmol} / 1)\end{array}$ & $0.9 \pm 0.1$ & $1.5 \pm 0.2$ & $<0.01$ \\
\hline
\end{tabular}

The values are mean \pm SEM. The groups were compared using the Student's $t$-test

\section{Lipolysis experiments}

Isolated fat cells were incubated as described in detail [23]. In brief, about $5-10,000$ cells per ml were incubated in duplicate at $37^{\circ} \mathrm{C}$ in Krebs-Ringer phosphate $(\mathrm{pH} \mathrm{7.4)} \mathrm{containing} \mathrm{albumin}$ $(20 \mathrm{~g} / 1)$, glucose $(1 \mathrm{~g} / \mathrm{l})$ and ascorbic acid $(0.1 \mathrm{~g} / \mathrm{l})$ in the absence or presence of increasing concentrations $\left(10^{-16}-10^{-4} \mathrm{~mol} / \mathrm{l}\right)$ of noradrenaline, isoprenaline, terbutaline, dobutamine, clonidine, forskolin or dibutyryl cyclic AMP. In the clonidine experiments adenosine deaminase $(1 \mathrm{mU} / \mathrm{l})$ was added to the incubation medium in order to remove traces of adenosine which may interfere with the antilipolytic effect of clonidine [23]. It is, however, not necessary to add adenosine deaminase in the experiments the lipolytic agonists, since adenosine has no effect on agonist sensitivity $\left(\mathrm{pD}_{2}\right)$ or maximum lipolytic effect as discussed [23]. After $2 \mathrm{~h}$, an aliquot was removed for the determination of glycerol [24]. The fat cells were viable during the whole study since the rate of glycerol release was linear for at least $4 \mathrm{~h}$. The same batches of collagenase and buffer ingredients were used throughout the study. The rate of lipolysis was expressed per $\mathrm{g}$ lipids, per unit cell surface area $\left(\mu \mathrm{mol}\right.$ of glycerol $\cdot 2 \mathrm{~h}^{-1} \cdot \mathrm{mm}^{-2}$ ) or per cell number $\left(\mu \mathrm{mol}\right.$ of glycerol $\cdot 2 \mathrm{~h}^{-1} \cdot 10^{7}$ cells $\left.^{-1}\right)$. In all subjects the agonists 
Table 2. Basal and maximum rates of lipolysis

\begin{tabular}{|c|c|c|c|c|c|c|c|c|}
\hline & \multicolumn{8}{|c|}{ Glycerol release } \\
\hline & \multicolumn{2}{|c|}{ Basal } & \multicolumn{2}{|c|}{ Noradrenaline } & \multicolumn{2}{|c|}{ Isoprenaline } & \multicolumn{2}{|c|}{ Forskolin } \\
\hline & Cell & Surface & Cell & Surface & Cell & Surface & Cell & Surface \\
\hline Control subjects & $5 \pm 1$ & $17 \pm 2$ & $15 \pm 1$ & $53 \pm 5$ & $28 \pm 2$ & $98 \pm 7$ & $26 \pm 2$ & $85 \pm 7$ \\
\hline Obese subjects & $14 \pm 1$ & $32 \pm 3$ & $27 \pm 3$ & $60 \pm 6$ & $40 \pm 4$ & $90 \pm 8$ & $36 \pm 4$ & $80 \pm 8$ \\
\hline$p$ & $<0.001$ & $<0.001$ & $<0.001$ & NS & $<0.01$ & NS & $<0.05$ & NS \\
\hline
\end{tabular}

The glycerol release is expressed per cell $\left(\mu \mathrm{mol} \cdot 2 \mathrm{~h}^{-1} \cdot 10^{7}\right.$ cells $\left.{ }^{-1}\right)$ or per cell surface area $\left(\mathrm{pmol} \cdot 2 \mathrm{~h}^{-1} \cdot \mathrm{mm}^{-2}\right)$. The values for noradrenaline, isoprenaline and forskolin are rates at the

Table 3. Correlation between fat cell volume and lipolysis

\begin{tabular}{ccccc}
\hline & Lipolysis & & & \\
\cline { 2 - 5 } & Basal & Noradrenaline & Isoprenaline & Forskolin \\
\hline$r$ & 0.65 & 0.54 & 0.52 & 0.49 \\
$p$ & $<0.001$ & $<0.001$ & $<0.001$ & $<0.001$ \\
\hline
\end{tabular}

The correlation between fat cell volume and lipolysis rate was determined by linear regression analysis. Lipolysis was related to fat cell number. Noradrenaline, isoprenaline and forskolin values are the rates at the maximum effective agonist concentrations. Results with control subjects and obese subjects were pooled together

always caused a dose-dependent stimulation or inhibition of glycerol release, which in each case reached a plateau at the highest agonist concentrations. $\mathrm{ED}_{50}$ was determined using computerized fitting of each dose-response curve as described previously [25]. The negative logarithm of the $\mathrm{ED}_{50}$ value $\left(\mathrm{pD}_{2}\right)$ was defined as adrenoceptor sensitivity.

\section{Beta-adrenoceptor binding studies}

The receptor binding studies have been described in detail [26]. Isolated fat cells $\left(20,000\right.$ cells per ml), were incubated at $37^{\circ} \mathrm{C}$ in $0.5 \mathrm{ml}$ of Krebs Ringer phosphate buffer ( $\mathrm{pH} 7.4)$ containing albumin $(5 \mathrm{~g} / 1)$, glucose $(1 \mathrm{~g} / \mathrm{l})$ and ascorbic acid $(0.1 \mathrm{~g} / 1)$. Saturation experiments were performed to determine the total amount of beta-adrenoceptors. The cells were incubated in duplicate for $60 \mathrm{~min}$ with six different concentrations of ${ }^{125} \mathrm{I}$-cyanopindolol. Non-specific binding (in the presence of $0.1 \mu \mathrm{mol} / 1$ of propranolol) was about $30 \%$ at low and about $45 \%$ athigh radioligand concentrations. In duplicate competition experiments, performed to determine the fraction of beta ${ }_{2}$-adrenoceptors in the total betareceptor population, $100 \mathrm{pmol} / 1$ of ${ }^{125} \mathrm{I}$-cyanopindolol competed with 12 increasing concentrations of the beta ${ }_{2}$-specific antagonist ICI 118,551 $\left(10^{-11}-10^{-4} \mathrm{~mol} / \mathrm{l}\right)$. Non-specific binding (at $10^{-4} \mathrm{~mol} / \mathrm{l}$ of ICI 118,551 ), was about $30 \%$. The saturation $\mathrm{ex}^{-}$ periments were evaluated by linear regression analysis of Scatchard plots [27]. Displacement curves were analysed by a non-linear least squares regression method [28] which provides an estimate of the relative proportions of high affinity beta ${ }_{2}$-receptors and low affinity beta ${ }_{1}$-receptors, as well as the affinity $\left(\mathrm{K}_{\mathrm{d}}\right)$ of these receptors for the displacing drug, ICI 118,551 [29]. The maximum total binding capacity obtained from saturation binding was multiplied with the fraction of high- and low-affinity binding sites for ICI 118,551. This represents the maximum binding

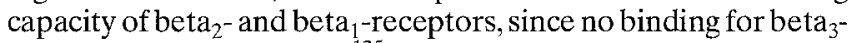
receptors is detected with ${ }^{125}$ I-cyanopindolol in the present type of experiments [30]. Binding capacity was expressed per unit cell surface area, which reflects the receptor density. maximum effective agonist concentration. $p=$ statistical comparison of values from control and obese subjects using Student's unpaired $t$-test. Values are mean \pm SEM

\section{Measurements of $m R N A$}

The solution hybridization assays for beta ${ }_{1}$ - and beta ${ }_{2}$-receptor mRNA in isolated fat cells have been described in detail [31]. Briefly, complementary oligonucleotide probes corresponding to nucleotide 739-789 for beta ${ }_{1}$-receptors and to nucleotide 772822 for beta ${ }_{2}$-receptors were synthesized in vivo with the plasmid pGEM-3 to produce cRNA, which was radiolabelled with $\left({ }^{35} \mathrm{~S}\right)$ UTP. About $150 \mu \mathrm{l}$ of adipocytes were homogenized and digested with proteinase $\mathrm{K}$ and total nucleic acids were extracted with phenol-chloroform. The $\left({ }^{35} \mathrm{~S}\right)$-UTP cRNA was hybridized at $70^{\circ} \mathrm{C}$ to total nucleic acid samples. Non-hybridized material was digested with RNase. RNase-resistant material was precipitated and collected on a glass filter. Sample hybridization was compared with a known amount of in vitro synthesized mRNA strand complementary to the radioactive probe. The amount of mRNA was related to the amount of DNA as described before [26] and to the amount of mRNA for the "bouse-keeping" gene beta-actin [32] which was also measured by solution hybridization in the extract [33].

\section{Drugs and chemicals}

Bovine serum albumin (fraction V, lot 63F-0748), Clostridium histolyticum collagenase type I, glycerol kinase from Escherichia coli (G4509), forskolin, dibutyryl cyclic AMP and dl-propranolol were obtained from Sigma (St Louis, Mo., USA). ( - ) - Isoprenaline hydrochloride came from Hässle (Mölndal, Sweden), terbutaline sulphate from Draco (Lund, Sweden), dobutamine hydrochloride from Eli Lilly (Indianapolis, Ind., USA) and ICI 118,551 from Cambridge Research Biochemicals Limited (Cheshire, UK). CGP 20712A was kindly supplied by Ciba Geigy (Basel, Switzerland). ATP monitoring reagent containing firefly luciferase was from LKB Wallac (Turku, Finland). pGEM-3 was from Promega Biotel (Madison, Wis., USA). SPG RNA polymerase and T7 RNA polymerase were obtained from Boehringer Mannheim (Mannheim, Germany). ${ }^{35}$ S-UTP and ${ }^{125}$ I-cyanopindolol were from New England Nuclear (Boston, Mass., USA). All other chemicals were of the highest grade of purity commerically available.

\section{Statistical analysis}

The Student's two-tailed $t$-test was used for comparison of data between and within groups. SEM was used as a measure of dispersion. In some cases linear or stepwise multiple regression analysis was performed. All statistics were determined by means of a software statistical package (Stat View II, 1987; Abacus Concepts, Inc, Berkeley, Calif., USA). Values for $\mathrm{K}_{\mathrm{d}}, \mathrm{ED}_{50}$ and $\mathrm{pD}_{2}$ were transformed into their logarithmic form when statistically examined. 

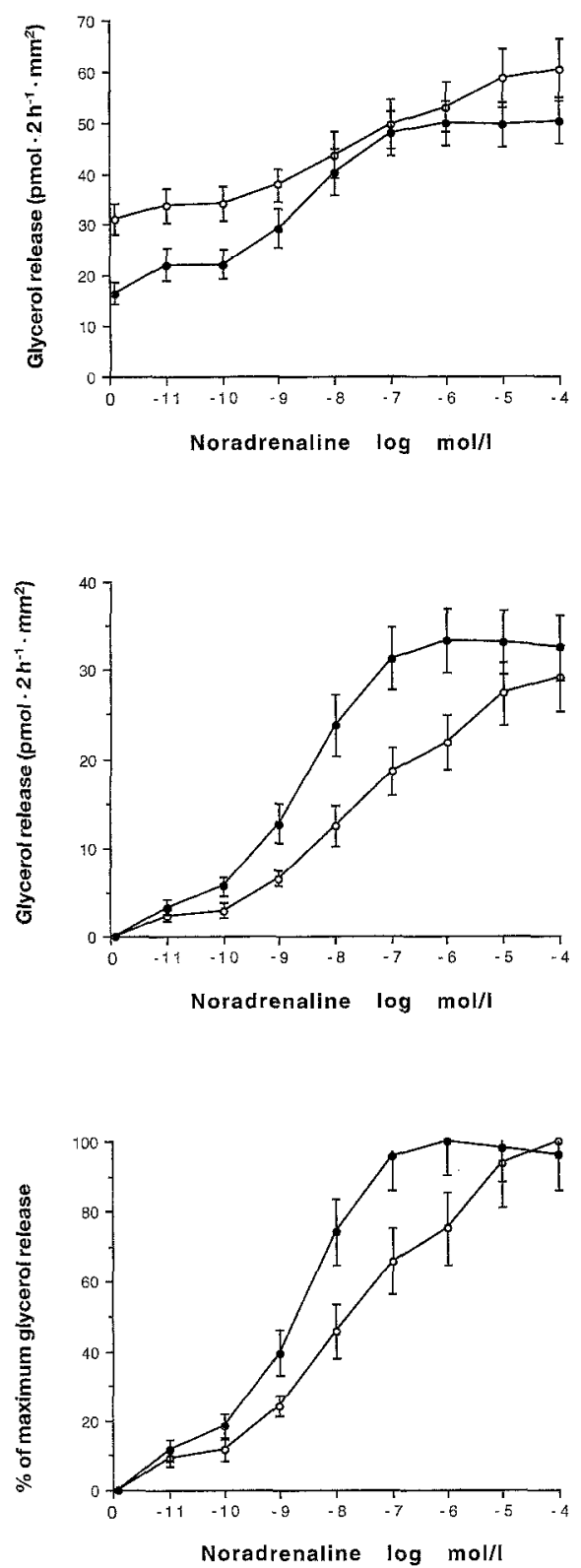

Fig. 1. Noradrenaline-induced lipolysis in control subjects (•) and obese subjects $(O)$. Isolated fat cells were incubated with or without the indicated concentrations of noradrenaline and glycerol release to the incubation medium was determined and used as lipolysis index. The mean dose-response curves are shown per unit cell surface area, with basal lipolysis included (top), or subtracted (center) and (bottom) in percent of glycerol release at the maximum effective hormone concentration (which was set at $100 \%$ )

\section{Results}

Clinical data are presented in Table 1 . There was no statistical difference in age between the groups. By definition the obese women had a higher BMI and waisthip ratio and, as expected, an increased fat cell volume compared to the non-obese women. Blood pressure as well as fasting plasma levels of insulin, glucose, glycerol, cholesterol, and triglycerides were increased in the obese women who also had decreased plasma HDLcholesterol. Total and free plasma cortisol levels were unexpectedly $30 \%$ lower in the obese group $(p<0.05)$. The plasma catecholamine level did not differ between the groups.

Data with basal and maximum stimulated glycerol release are found in Table 2. The rates of forskolin-, isoprenaline- and noradrenaline-induced lipolysis per unit cell surface area at the maximum effective agonist concentrations were similar in obese compared to nonobese women. The same was true for lipolysis induced by dibutyryl cyclic AMP (data not shown). However, the maximum agonist-induced rate of lipolysis per cell number was increased in the obese women. Basal lipolysis, on the other hand, was increased in the obese subjects regardless of the use of denominator for glycerol release. Since fat cell volume differed markedly between the groups, the observed variations in lipolysis per cell number may reflect variations in cell size. This was tested using linear regression analysis of glycerol release/cell number vs fat cell volume (Table 3 ). All lipolysis parameters were significantly dependent on fat cell volume ( $r$ from 0.5 to 0.7 ).

Figure 1 shows the mean dose response curves for noradrenaline in the two groups. Noradrenaline caused a dose-dependent stimulation of lipolysis. The obese subjects had a high basal rate of lipolysis but a reduced effect of the addition of noradrenaline which is most evident when the basal values are subtracted. To further evaluate hormone sensitivity the dose-response curves were plotted relative to the maximum lipolytic effect. In this case the results are completely independent of the denominator used or of basal lipolysis. The mean dose-response curve for the obese subjects was then markedly shifted to the right compared to that of the control subjects. At $10^{-8} \mathrm{~mol} / \mathrm{l}$ of noradrenaline (which is a plasma concentration usually observed during physiological challenge) lipolysis was stimulated by $80 \%$ of the maximum rate in control subjects and only by $40 \%$ in the obese subjects.

Lipolytic catecholamine sensitivity was further investigated in experiments with more selective adrenergic agonists (Fig.2). The mean dose-response curves for the non-selective beta-agonist isoprenaline and the selective beta $_{2}$-agonist terbutaline were shifted to the right in the obese compared to the control subjects. On

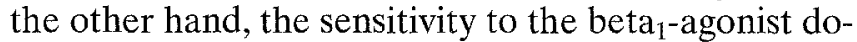
butamine and the alpha $a_{2}$-agonist clonidine was not influenced by obesity nor was there any difference between groups as regards the maximum antilipolytic effect of clonidine ( $70-80 \%$ inhibition of the basal rate).

The individual values for lipolytic sensitivity of the adrenergic agonists $\left(\mathrm{pD}_{2}\right)$ were statistically compared in Table 4 . The sensitivity to noradrenaline and terbutaline was decreased by 10 -fold $(p<0.01)$ and to isoprenaline, by almost 100 -fold $(p<0.001)$ in obesity. No significant difference between the groups was observed regarding sensitivity to dobutamine or clonidine.

The intrinsic activities (maximum lipolytic action in relation to maximum lipolytic action of isoprenaline) were $0.90 \pm 0.03$ and $0.92 \pm 0.2$ for terbutaline in the 

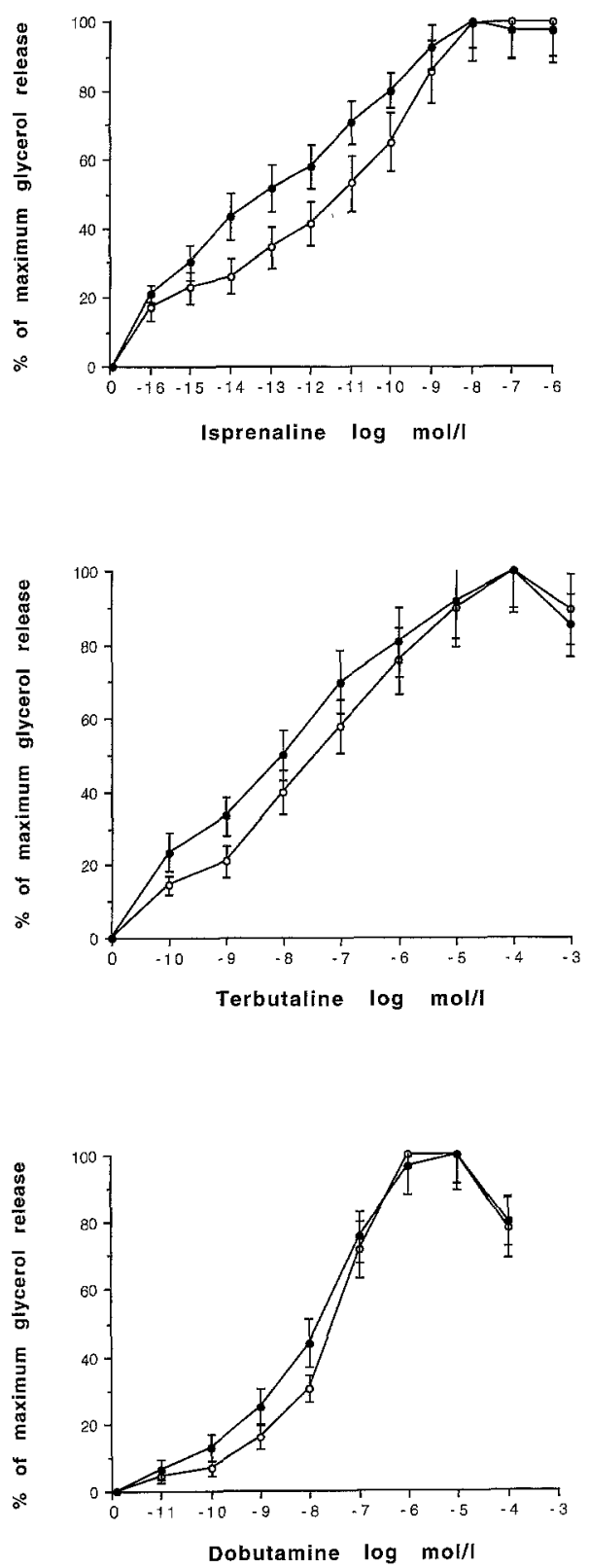

Fig. 2. Lipolysis induced by isoprenaline (non-selective betaagonist), terbutaline (selective beta ${ }_{2}$-agonist) and dobutamine

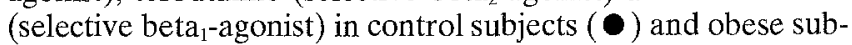
jects $(O)$. The mean dose response curves are shown as percent of glycerol release at the maximum effective hormone concentration (which was set at $100 \%$ )

control and obese groups, respectively. The corresponding values for dobutamine were $0.92 \pm 0.02$ and $0.93 \pm 0.02$. These values did not differ significantly between the groups.

Data with radioligand binding are shown in Table 5. The maximum binding to beta ${ }_{2}$-adrenoceptors was reduced by about $70 \%$ in the obese compared to the nonobese women $(p<0.01)$. Neither the maximum bind-

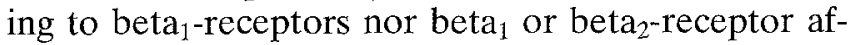
finity $\left(K_{d}\right.$ for ICI, 118,551) were altered in obesity. The total number of beta receptor binding sites per cell did not differ significantly between the two groups. $K_{d}$ for the radioligand ${ }^{125} \mathrm{I}$-cyanopindolol in the saturation binding experiments was $65 \pm 8$ and $78 \pm 10$, respectively, in control and obese subjects. These values did not differ significantly. The Hill coefficient in the saturation binding experiments was $0.95 \pm 0.03$ in both groups together, which was not significantly different from 1.0.

The steady-state mRNA levels for beta $1^{-}$and beta $a_{2}$-adrenoceptors were similar in obese and control subjects. The values were $929 \pm 156$ and $1176 \pm$ $154 \mathrm{amol} / \mu \mathrm{g}$ DNA, respectively, for beta $\mathrm{a}_{1}$ and 1063 \pm 123 and $1024 \pm 124 \mathrm{amol} / \mu \mathrm{g}$, for beta 2 . Beta-adrenoceptor mRNA was also related to mRNA for the "house-keeping" gene beta-actin. These values (amol of beta-receptor subtype mRNA/amol of beta-actin mRNA) were also similar in obese and control subjects: $0.49 \pm 0.14$ and $0.48 \pm 0.12$, respectively, for beta ${ }_{1}-$ receptors and $0.52 \pm 0.15$ and $0.42 \pm 0.15$, for beta 2 -receptors.

The relationship between lipolytic noradrenaline sensitivity BMI was also investigated (Table 6). Linear regression analysis showed a significant negative correlation $(-0.49)$ between noradrenaline sensitivity and BMI. Since BMI may be influenced by several factors, a stepwise multiple regression analysis was performed using BMI as the dependent variable and age, noradrenaline-sensitivity, waist-hip ratio, fat cell volume, basal lipolysis as well as plasma insulin and total cortisol levels as independent variables. The variable with the highest partial correlation coefficient was entered at each step until no variable remained with an $F$-value of 4 or more. Noradrenaline sensitivity and fat cell volume were the only regressors that significantly contributes to the relationship. Fat cell volume entered as the first step $(F=100)$ and noradrenaline sensitivity as the last step $(F=11)$. Adjusted $r^{2}$ for these two variables together in the regression was 0.76 . Plasma insulin, which was a strong regressor in single regression analysis $(r=0.68)$ failed to contribute to the variation in BMI using the stepwise analysis $(F=1.1)$. Comparing the total and partial correlation coefficients in Table 6 it can be noted than the $r$-value for noradrenaline $\mathrm{pD}_{2}$ was almost the same in single and multiple regression, whereas for all other parameters it was much lower in multiple than in single regression analysis. Neither age nor free plasma cortisol showed any significant relation to BMI nor to any of the lipolysis or receptor binding parameters (data not shown).

\section{Discussion}

This study describes for the first time a cellular defect in lipolysis regulation which may contribute to the development of upper-body obesity in women. These women displayed many characteristics of the abdominal type of obesity; insulin resistance, increased blood pressure and dyslipidaemia. The fat cell volume differed markedly between the obese and the non-obese women. This difference does not affect evaluation of the sensitivity of the cells to hormone action $\left(\mathrm{pD}_{2}\right)$, 
Table 4. Sensitivity to adrenergic agonists in control subjects and obese subjects

\begin{tabular}{|c|c|c|c|c|c|}
\hline & \multicolumn{5}{|l|}{$\mathrm{pD}_{2}$} \\
\hline & Noradrenaline & Isoprenaline & Terbutaline & Dobutamine & Clonidine \\
\hline Control subjects & $\begin{array}{l}8.5 \\
\pm 0.2\end{array}$ & $\begin{array}{l}12.8 \\
\pm 0.4\end{array}$ & $\begin{array}{l}8.4 \\
\pm 0.3\end{array}$ & $\begin{array}{l}7.6 \\
\pm 0.2\end{array}$ & $\begin{array}{l}9.8 \\
\pm 0.2\end{array}$ \\
\hline Obese subjects & $\begin{array}{l}7.4 \\
\pm 0.2\end{array}$ & $\begin{array}{l}11.2 \\
\pm 0.3\end{array}$ & $\begin{array}{l}7.4 \\
\pm 0.2\end{array}$ & $\begin{array}{l}7.4 \\
\pm 0.1\end{array}$ & $\begin{array}{l}9.5 \\
\pm 0.2\end{array}$ \\
\hline
\end{tabular}

$\mathrm{pD}_{2}$ is the negative logarithm of the concentration (mol/1) of adrenergic agonist giving half-maximum effect in the lipolysis dose-response experiments. The values (mean \pm SEM) were statistically compared using Student's unpaired $t$-test

Table 5. Beta ${ }_{1}$-and beta ${ }_{2}$-adrenoceptor binding parameters

\begin{tabular}{|c|c|c|c|c|}
\hline & \multicolumn{2}{|c|}{ Binding capacity $\left(\mathrm{amol} / \mathrm{um}^{2}\right)$} & \multicolumn{2}{|c|}{ Binding affinity $(\log \mathrm{mol} / \mathrm{l})$} \\
\hline & Beta $_{1}$ & $\mathrm{Beta}_{2}$ & Beta $_{1}$ & Beta $_{2}$ \\
\hline Control subjects & $1.6 \pm 0.2$ & $2.6 \pm 0.3$ & $-5.5 \pm 0.1$ & $-7.8 \pm 0.1$ \\
\hline$p$ & NS & $<0.001$ & $\mathrm{NS}$ & NS \\
\hline
\end{tabular}

Receptor binding was determined as described in Subjects and methods and is expressed per unit of cell surface area. Maximum binding capacity of ${ }^{125}$ I-cyanopindolol was obtained from saturation and displacement experiments. Binding affinity is the $\mathrm{K}_{\mathrm{d}}$ of

ICI 118,551 for high- $\left(\right.$ beta $\left._{2}\right)$ and low-affinity (beta ${ }_{1}$ ) binding sites. $p$ is statistical comparison of controls vs obese using Student's unpaired $t$-test. Values are mean \pm SEM

Table 6. Correlation between BMI and clinical or adipocyte parameters

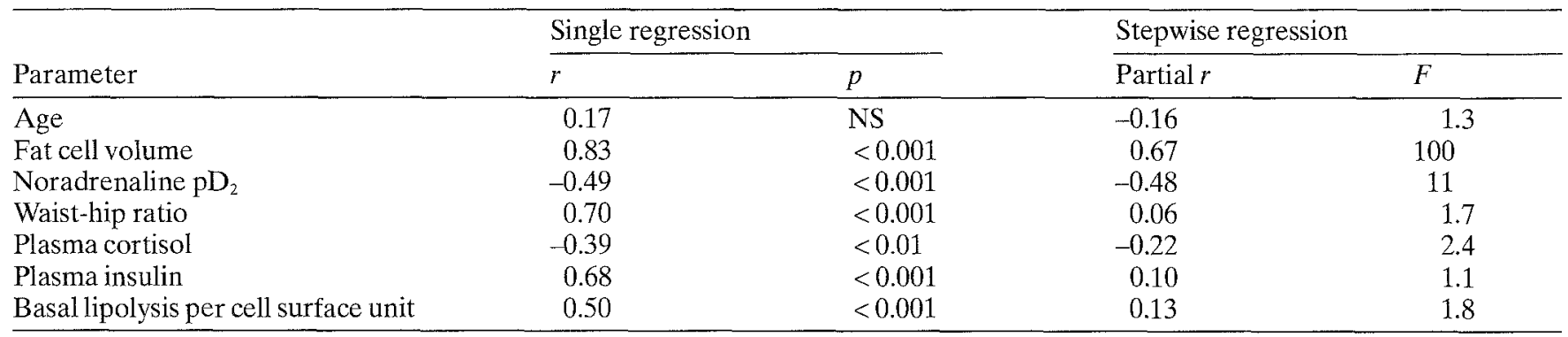

All parameters were included together in the multiple regression analysis. Each regressor with an $F$-value of 4.0 or more was considered to contribute significantly to the relationship with BMI

which is the major aspect of lipolysis regulation examined in this study. It is, however, necessary to consider the use of a proper denominator for the maximum rates of catecholamine-induced lipolysis, since results based on cell number or unit of cell surface area usually differ when a difference in fat cell volume is found in the investigated material [34-37]. We found that lipolysis rates per cell correlated significantly with fat cell volume $(r=0.5-0.7)$, making it impossible to know to which extent the observed differences in lipolysis per cell number between the groups only reflected the differences in fat cell volume. Considering that the interaction of catecholamines with the fat cell is at the surface of the plasma membrane, we have chosen to express data per unit of cell surface area which may be more physiological in a hormone study, as pointed out previously [34-37].

A 10-fold decrease in the lipolytic sensitivity of noradrenaline was observed in obese compared to nonobese subjects. At a physiological noradrenaline con- centration $(10 \mathrm{nmol} / \mathrm{l})$ the adipocytes of the obese only reached $40 \%$ of their maximum lipolytic capacity while lipolysis was almost maximally stimulated in the cells of the control subjects. These data confirm previous in vivo findings as regards lipolytic noradrenaline resistance in upper-body obesity [6]. When the influence of cell size is accounted for, our data suggest normal maximum lipolytic capacity, increased basal lipolysis rates and a blunted response to catecholamine stimulation in fat cells of upper-body obese women. This may indicate a decreased ability of the obese to mobilize lipids during physiological challenge such as fasting or exercise in spite of increased lipolytic rate at rest.

The cellular mechanism responsible for the observed catecholamine resistance in obesity was solely localized to the beta $a_{2}$-adrenoceptors. The antilipolytic function of alpha $a_{2}$-receptors as well as beta -receptor $_{1}$ density and lipolytic sensitivity were normal in obese women, while a 10 -fold reduction in beta ${ }_{2}$-receptor subtype sensitivity was found in adipocytes of the obese 
subjects. A $70 \%$ reduction in the cell surface density of beta $_{2}$-receptors was found. This may explain the observed catecholamine resistance but it is possible that additional defects in the coupling of beta $a_{2}$-receptors to the so-called $\mathrm{G}_{\mathrm{s}}$-protein also are present in obesity. Whether the decrease in beta $a_{2}$-adrenoceptor density is due to changes in synthesis, degradation or internalization of the receptor subtype remains to be established. Unfortunately, it is not possible to study these processes (or coupling) in the small amounts of adipose tissue which can be obtained clinically. However, the negative findings with beta-receptor mRNA suggest alterations at a level beyond gene expression (i.e. posttranscriptionally).

The question remains whether the observed abnormality in lipolysis regulation of obese subjects is associated primarily or secondarily with the obese state. This might possibly be answered by investigating lipolysis in post-obese subjects. It is an intriguing possibility that disturbances in cortisol metabolism might contribute to the lipolysis defect. As reviewed [2], cortisol improves beta ${ }_{2}$-adrenergic effects in fat cells. The fasting plasma free cortisol level in the obese women was twothirds of that of the non-obese women. This suggests that there might be some defect in cortisol metabolism in women with upper-body obesity. As discussed recently [38] previous investigations of cortisol in obesity have demonstrated low or normal total circulating levels but increased urinary levels. Insulin is a potent antilipolytic agent which interacts with catecholamines and exerts a rapid effect on lipolysis in vitro which can at least in part be mediated by down-regulation of betaadrenoceptors in human fat cells [39]. This acute effect of insulin on adrenoceptors is however non-selective as regards the receptor subtypes (P.Arner and Marcus, unpublished observations). On the other hand, it is possible that the mild but chronic hyperinsulinaemia found in the obese could have selective down-regulatory effects on beta $a_{2}$-adrenoceptor function in obesity.

The recently cloned beta 3 -adrenoceptor is also present in human fat cells at the level of mRNA [40]. However, previous data suggest that this receptor is poorly expressed on a functional level in human subcutaneous adipose tissue [30,41]. Although, some of the present data with noradrenaline can be influenced by this receptor subtype it is not likely that the findings with terbutaline or dobutamine are influenced by interactions with the beta ${ }_{3}$-receptor. Likewise, the Hill coefficient for ${ }^{125} \mathrm{I}$ cyanopindolol was almost 1.0, suggesting almost no contribution of beta $a_{3}$-receptors to the results with binding.

The extent to which catecholamine resistance in fat cells can contribute to the development of obesity is unknown. Stepwise regression analysis suggested that noradrenaline sensitivity, and fat cell volume together were responsible for $76 \%$ of the variations in BMI among the subjects. This figure is surprisingly high considering the large number of possible factors which were not tested and which may contribute to the development of obesity in a particular individual.
Some information about adrenoceptor sensitivity in obese men with abdominal obesity is available, showing normal beta-receptor activity but increased alpha ${ }_{2}^{-}$ receptor activity in abdominal subcutaneous fat cells [42]. These data are entirely different from the present findings and suggest that the pathogenesis of obesity in men and women differs markedly regarding involvement of defects in lipolysis regulation. Sex variations are possible, considering the differences in fat distribution, lipolysis regulation and complications of obesity that exist among women and men [43].

We do not know how our data relate to adipocytes in other regions than the subcutaneous abdominal site. We studied the latter region because it is more sensitive to regulation than peripheral subcutaneous adipose tissue [42]. Studies of men, though, have revealed regional differences in the influence of obesity on lipolysis regulation [42]. Furthermore, the present study included only upper-body obese women and does therefore not address the issue of possible differences between obese women with different body composition. A recent in vivo study [6] has indeed shown that the lipolytic rates differ between upper- and lowerbody obese women.

In summary, the present study shows for the first time a cellular defect in lipolysis regulation which may contribute to the development of abdominal obesity in women. Adipocytes of these subjects are resistant to catecholamines due to decreased cell surface density of beta ${ }_{2}$-adrenoceptors, which in turn may be due to a post-transcriptional defect in receptor subtype expression. Whether this defect is primarily or secondarily associated with obesity or involves abnormalities in circulating free cortisol remains to be established.

Acknowledgements. This study was supported by grants from the Swedish Medical Research Council, the Swedish Diabetes Association, the Karolinska Institute, the Foundations of Osterman, Wiberg, Nordic Insulin, Old Female Servants, Golje, King Gustav $\mathrm{V}$ and Trygg-Hansa.

\section{References}

1. Ravussin E, Bogardus C (1991) A brief overview of human energy metabolism and its relationship to essential obesity. Am J Clin Nutr 55: 242S-245S

2. Arner P (1992) Adrenergic receptor function in fat cells. Am J Clin Nutr 55: 228S-236S

3. Lafontan M, Berlan M (1981) Alpha adrenergic receptors and the regulation of lipolysis in adipose tissue. Trends Pharmacol Sci 2: 126-129

4. Arner P (1988) Control of lipolysis and its relevance to development of obesity in man. Diabetes Metab Rev 5: 507-515

5. Wolfe RR, Peters EJ, Klein S, Holland OB, Rosenblatt J, Gary H Jr (1987) Effect of short-term fasting on lipolytic responsiveness in normal and obese human subjects. Am J Physiol 252: E189-E196

6. Jensen MD, Haymond MW, Rizza RA, Cryer PE, Miles JM (1989) Influence of body fat distribution on free fatty acid metabolism in obesity. J Clin Invest 83: 1168-1173 
7. Connacher AA, Bennet WM, Jung RT et al. (1991) Effect of adrenaline infusion on fatty acid and glucose turnover in lean and obese human subjects in the post-absorptive and fed states. Clin Sci 81: 635-644

8. Lafontan M (1981) Alpha-adrenergic responses in rabbit white fat cells: the influence of obesity and food restriction. J Lipid Res 22: 1084-1093

9. French RR, York DA (1984) The regulation of adenylate cyclase in adipocyte plasma membrane from genetically obese (ob/ob) mice. Diabetologia 26: 466-472

10. Taouis M, Valet P, Estan L, Lafontan M, Montastruc P, Berlan M (1989) Obesity modifies the adrenergic status of dog adipose tissue. J Pharmacol Exp Ther 250: 1061-1066

11. Carpéné C, Rebourcet MC, Guichard C, Lafontan M, Lavau M (1990) Increased alpha $a_{2}$-adrenergic binding sites and antilipolytic effect in adipocytes from genetically obese rats. J Lipid Res 31: 811-819

12. Muzzin P, Revelli J-P, Kuhne F et al. (1991) An adipose tissue-specific beta-adrenergic receptor. J Biol Chem 266: 24053-24058

13. Krotkiewski M (1988) Can body fat patterning be changed? Acta Med Scand 723 [Suppl]: 213-223

14. Hjelmdahl P (1987) Catecholamine measurements in plasma by high-performance liquid chromatography with electrochemical detection. Methods Enzymol 142: 521-534

15. Rodbell M (1964) Metabolism of isolated fat cells. I. Effects of hormones on glucose metabolism and lipolysis. J Biol Chem 239: 375-380

16. Di Girolamo M, Mendlinger S, Fertig JW (1971) A simple method to determine fat cell size and number in four mammalian species. Am J Physiol 221: 850-858

17. Hirsch J, Gallian E (1968) Methods for determination of adipose cell size and number in man and animals. $J$ Lipid Res 9: 110-119

18. Dole VP, Meinertz H (1960) Microdetermination of longchain fatty acids in plasma and tissue. J Biol Chem 235: 25952599

19. Landin KP, Lönnroth P, Krotkiewski M, Holm G, Smith U (1990) Increased insulin resistance and fat cell lipolysis in insulin resistance and fat cell lipolysis in obese but not lean women with a high waist/hip ratio. Eur J Clin Invest 20:530535

20. Rebuffé-Scrive M, Andersson B, Olbe L, Björntorp P (1990) Metabolism of adipose tissue in intraabdominal depots in severely obese men and women. Metabolism 39: 1021-1025

21. Landin K, Lönnroth P, Krotkiewski M, Holm G, Smith U (1990) Increased insulin resistance and fat cell lipolysis in obese but not lean women with a high waist hip ratio. Eur $\mathbf{J}$ Clin Invest 20: 530-535

22. Kather HE, Wieland EW, Scheurer A, Vogel G, Widenberg U, Joose C (1987) Influences of variation in total energy intake and dietary composition. J Clin Invest 80: 566-572

23. Wahrenberg H, Lönnqvist F, Arner P (1989) Mechanisms underlying regional differences in lipolysis in human adipose tissue. J Clin Invest 84: 458-467

24. Hellmér J, Arner P, Lundin A (1989) Automatic luminometric kinetic assay of glycerol for lipolysis studies. Anal Biochem 177: 132-137

25. Östman J, Arner P, Kimura H, Wahrenberg H, Engfeldt P (1984) Influence of fasting on lipolytic response to adrenergic agonists and on adrenergic receptors in subcutaneous adipocytes. Eur J Clin Invest 14: 383-391

26. Lönnqvist F, Wahrenberg H, Hellström L, Reynisdottir S, Arner P (1992) Lipolytic catecholamine resistance due to de- creased beta $\mathrm{a}_{2}$-adrenoceptor expression in fat cells. J Clin Invest $90: 2175-2186$

27. Scatchard G (1948) The attractions of proteins for small molecules and ions. Ann NY Acad Sci 51: 660-672

28. Munson PJ, Rodbard D (1980) LIGAND: a versatile computerized approach for characterization of ligand binding systems. Anal Biochem 107:220-239

29. Mauriége P, DePergola G, Berlan M, Lafontan M (1988) Human fat cell beta-adrenergic receptors. Beta-agonist dependent lipolytic responses and characterization of betaadrenergic binding sites on human fat cell membranes with highly selective beta ${ }_{1}$-antagonists. J Lipid Res 29: 587-601

30. Langin D, Portillo M, Saubnier-Blanche JS, Lafontan M (1991) Co-existence of three beta-adrenoceptor subtypes in white fat cells of various mammalian species. Eur J Pharmacol 199: 291-301

31. Arner P, Hellström L, Wahrenberg H, Brönnegård M (1990) Beta-adrenoceptor expression in human fat cells from different regions. J Clin Invest 86: 1595-1600

32. Cleveland DW, Lopata MA, MacDonald RJ, Cowan NJ, Rutter WJ, Kinschner MW (1980) Number and evolutionary conservation of alpha- and beta-tubulin and cytosplamatic beta- and gamma-actin genes using specific cloned cDNA probes. Cell 20: 95-105

33. Arner $P$, Lithell $H$, Wahrenberg H, Brönnegård M (1991) Expression of lipoprotein lipase in different human subcutaneous regions. J Lipid Res 32: 423-429

34. Zinder O, Shapiro B (1971) Effect of cell size on epinephrine- and ACTH-induced fatty acid release from isolated fat cells. J Lipid Res 12: 91-95

35. Giudicelli Y, Pecquery R (1980) Beta-adrenergic receptors and catecholamine-sensitive adenylate cyclase in rat-cell membranes: influence of growth, cell size and aging. Eur J Biochem 90: 413-419

36. Byung P, Bertrand HA, Masoro EJ (1980) Nutrition-aging influence of catecholamine-promoted lipolysis. Metabolism 29: 438-444

37. Marcus C, Karpe B, Bolme P, Sonnenfeldt T, Arner P (1987) Changes in catecholamine-induced lipolysis in isolated human fat cells during the first year of life. J Clin Invest 79: $1812-1818$

38. Mårin P, Darin N, Amemiya T, Andersson B, Jern S, Björntorp P (1992) Cortisol secretion in relation to body fat distribution in obese premenopausal women. Metabolism 41: $882-886$

39. Engfeldt P, Hellmér J, Wahrenberg H, Arner P (1988) Effects of insulin on adrenoceptor binding and the rate of catecholamine-induced lipolysis in isolated human fat cells. J Biol Chem 30: 15553-15560

40. Krief S, Lönnqvist F, Raimbault S et al. (1993) Tissue dis-

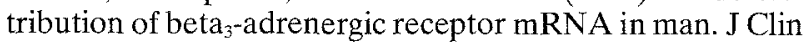
Invest 91:344-349

41. Hollenga C, Brouwer F, Zaagsma J (1991) Differences in functional cyclic AMP compartments mediating lipolysis by isoprenaline and BRL 37344 in four adipocyte types. Eur J Pharmacol 200: 325-330

42. Mauriège P, Després JP, Prud'homme D et al. (1991) Regional variation in adipose tissue lipolysis in lean and obese men. J Lipid Res 32: 1625-1633

43. Björntorp P (1991) Metabolic implications of body fat distribution. Diabetes Care 14: 1132-1143 